\title{
PLEISTOCENE MOLLUSCA FROM THE RAISED BEACH DEPOSITS OF PERIM ISLAND.
}

\author{
By the Rev. R. Ashington Bullen, F.L.S., ete.
}

Read 14th June, 1901.

The shells named in this paper were collected by Mr. J. A. Rupert Jones, R.N.R., Assistant Harbour Master, etc., at Perim Island. They are all from the expanse of raised beach known as 'Sheikh Berkhud' (so-named from the tomb of that Mahometan saint which stands near the northernmost sandpit on the north side of Perim Island). The raised beach is about 20 feet above low-water mark.

One large Tridacna, not forwarded, measured $18 \times 10$ inches and rather over an inch thick. The raised beach is a flat level plain of coral formation, extending inland to the basalt hills, 203 feet in height, and is covered in places with patches of low scrub.

Among the specimens received are two recent ones which were probably blown inland during storms; at any rate, they show no evidence of having been an integral part of the raised-beach deposit, being quite without the breccia-matrix which distinguishes the rest of the collection.

Mr. R. Bullen Newton, who has so recently worked over the whole of the literature and collections of the raised-beach deposits of the Red Sea area in the British Museum, ${ }^{1}$ has very kindly looked over my specimens, and as a result seven hitherto unrecorded Pleistocene species are now added to those already known. They are Conus striatus, Natica mammilla, Lamprostoma fammulatus, Vertagus obeliscus, V. vulgaris, Barbatia setigera, and Lima squamosa. My best thanks are due to Mr. Bullen Newton for the trouble he has taken.

\section{LIST OF MOLLUSCA FROM PERIM ISLAND. ${ }^{2}$}

Bulla ampulla (Linn.).

Canarium gibberulum (Linn.). , dentatum, var. ery. thrinum (Chem.).

Cerithium Rueppeli, Philippi. Conus flavidus, Lamk. * ,, striatus, Linn.
Conus virgo, var. emaciatus, Reeve.

Cyprea erosa, Linn.

Fusus polygonoides, Lamk.

Melongena (Volema) paradisiaca, Reeve.

Nassa pulla, Linn.

1 Geol. Mag., N.s., dec. iv, vol. vii, Nov. and Dec., 1900.

2 New records are marked with an asterisk. 
* Natica mammilla (Linn.). Nerita albicilla, Linn.

Oliva (Carmione) inflata, Lamk. Pleurotoma Garnonsii, Reeve.

Purpura hippocastanum, Lamk. Solarium perspectivum (Linn.). Strombus tricornis, Lamk. Terebra consobrina, Desh.

Anadara antiquata (Linn.). Asaphis deflorata (Linn.). * Barbatia setigera (Reeve). Cardium rubicundum, Born. Codakia exasperata (Reeve). Glycimeris pectunculus (Linn.).
Terebra duplicata (Linn.).

*Trochus (Lamprostoma) fammulatus, Lamk.

Turbo radiatus, Gmelin.

Vasum cornigerum (Lamk.).

* Tertagus obeliscus (Brug.).

* , vulgaris, Schum.

Libitina oblonga (Linn.). * Lima squamosa, Lamk. Spondylus (?) aculeatus, Chem. Tellina remies, Linn. Tridacna gigas (Linn.). Venus reticulata, Linn. 


\section{$2 \mathrm{BHL}$ Biodiversity Heritage Library}

Bullen, R. Ashington. 1901. "PLEISTOCENE MOLLUSCA FROM THE RAISED BEACH DEPOSITS OF PERIM ISLAND." Proceedings of the Malacological Society of London 4, 254-255.

View This Item Online: https://www.biodiversitylibrary.org/item/53747

Permalink: https://www.biodiversitylibrary.org/partpdf/202735

\section{Holding Institution}

Smithsonian Libraries

\section{Sponsored by}

Smithsonian

\section{Copyright \& Reuse}

Copyright Status: Public domain. The BHL considers that this work is no longer under copyright protection.

This document was created from content at the Biodiversity Heritage Library, the world's largest open access digital library for biodiversity literature and archives. Visit BHL at https://www.biodiversitylibrary.org. 